\title{
Use of a conditioning unit at the haymaking of Tifton 85 overseeded with Avena sativa or Lolium multiflorum
}

\author{
Deise Dalazen Castagnara ${ }^{1}$, Marcela Abbado Neres $^{1}$, Paulo Sérgio Rabello de Oliveira ${ }^{1}$, \\ Cloves Cabreira Jobim² ${ }^{2}$, Tamara Taís Três ${ }^{2}$, Eduardo Eustáquio Mesquita ${ }^{1}$, Maximilliane \\ Alavarze Zambom ${ }^{1}$
}

\footnotetext{
1 Universidade Estadual do Oeste do Paraná - Rua Pernambuco, 1777, Centro, Marechal Cândido Rondon - PR, 85960-000.

2 Universidade Estadual de Maringá UEM - Av. Colombo, 1790, Jd. Universitário, Maringá - PR, 87020-900.
}

\begin{abstract}
White oat and ryegrass were overseeded on Tifton 85 pastures for evaluation of dry matter yield (DMY), leaf:stem ratio (L:S), dehydration curves and nutritional value of forages. Dry matter intake and L:S ratio were analyzed using a completely randomized blocks design with five forage growth conditions (single Tifton 85 and intercropped with white oat or ryegrass, and white oat or ryegrass intercropped with Tifton 85), whereas for drying curves, ten dehydration times were tested $(0,4,8,24,28,32,48,52,56$ and 71 hours after harvest) by a $5 \times 10$ split-plot arrangement (growth conditions of forages as main plot and dehydration times as sub-plots). The nutritive value data were analyzed in a $3 \times 3$ split-plot trial with single Tifton 85, Tifton 85 - Oat and Tifton 85-Ryegrass as main plots and the three sampling times (before harvesting, at baling and 100 days after storage) as sub-plots. Oat and ryegrass showed higher L:S ratio, while the intercrops of Tifton 85 - Oat and Tifton 85 - Ryegrass presented lower DMY, but higher crude protein concentration and in vitro DM digestibility than single Tifton. Neutral and acid detergent fiber concentrations were higher for single Tifton 85. Ryegrass and white oat, overseeded on Tifton 85 pasture, improved the nutritional value of the hay produced; however, in a 100-day storage period, there was a reduction in in vitro dry matter digestibility and crude protein concentrations.
\end{abstract}

Key Words: Cynodon, haymaking, in vitro dry matter digestibility, oat, ryegrass

\section{Introduction}

The production of high-quality forage is a basic and crucial condition for cattle breeding, as it is supplied as pasture or preserved by hay or silage processes. Therefore, the right technology in feedstuff production is essential (Jobim et al., 2007). Hay is a forage preservation form that makes its bulk management easier and shows a good nutritional value when well-prepared and stored (Domingues, 2009).

Cultivars and hybrids of Cynodon genus have stood out by their high productivity and increased nutritive values. However, as a characteristic of tropical forages species, Tifton 85 presents production seasonality, so, there is some reduction of dry matter production from May to September, according to the weather conditions of the region. Such dry matter reduction, during the coldest periods of the year, could be supplemented with annual overseeded forages that are adapted to cold weather, such as oat and ryegrass. In grazing areas, the overseeded management causes significant increase in the quantity and quality of forage, according to trials carried out by Reis et al. (2001) and Moreira et al. (2006).

Both oat and ryegrass are species with different structural characteristics of Tifton 85, with emphasis on the oat that shows a thicker stem. So, because of this, such forage needs different practices of management that cause injuries to the stem and which increase and homogenize dehydration. Among the equipments used to promote these injuries, there are the conditioning units that increase the dehydration rate of some plants in the field, so, the drying time of hay decreases, as well as the risk of rains. The injuries promoted by the conditioning units have shown beneficial effect at the final stage of dehydration, when water loss is slower and occurs by the cuticle; however, the use of conditioning units may cause changes in chemical composition and digestibility of the forage.

This study was carried out to determine the dry matter production and leaf:stem ratio, and to estimate the dehydration curve, chemical composition, in vitro dry matter digestibility and crude protein of single Tifton 85 hay or Tifton 85 overseeded with white oat or annual ryegrass, using a conditioning unit. 


\section{Material and Methods}

The experiment was conducted in field conditions on the Experimental Farm Antônio Carlos dos Santos Pessoa, which belongs to Universidade Estadual do Paraná, campus Marechal Cândido Rondon, having as coordinates latitude $24^{\circ} 33^{\prime} 40^{\prime \prime} \mathrm{S}$, longitude $54^{\circ} 04^{\prime} 12^{\prime \prime} \mathrm{W}$ and altitude $420 \mathrm{~m}$. The local weather is classified according to Koppen Cfa as subtropical with rainfalls well distributed during the year and hot summers. The average temperatures of the coldest quarter vary from 17 to $18{ }^{\circ} \mathrm{C}$. The warmest quarter varies from 28 to $29^{\circ} \mathrm{C}$ and the yearly average temperature, from 22 to $23^{\circ} \mathrm{C}$. The total annual average of rainfalls range from 1,600 to $1,800 \mathrm{~mm}$ for this region and the wettest quarter shows total records that vary from 400 to $500 \mathrm{~mm}$ (IAPAR, 2006). During the growth and drying of plants, weather conditions were favorable (Table 1).

The soil of the experimental area is classified as Oxisol (EMBRAPA, 2006) with the following chemical characteristics: $\mathrm{pH}$ in water: 5.70; $\mathrm{P}$ (Mehlich): $10.78 \mathrm{mg} /$ $\mathrm{dm}^{3}$; K (Mehlich): $0.13 \mathrm{cmol}_{\mathrm{c}} / \mathrm{dm}^{3} ; \mathrm{Ca}^{2+}(\mathrm{KCl} 1 \mathrm{~mol} / \mathrm{L})$ : $5.21 \mathrm{cmol}_{\mathrm{C}} / \mathrm{dm}^{3} ; \mathrm{Mg}^{2+}(\mathrm{KCl} 1 \mathrm{~mol} / \mathrm{L}): 0.91 \mathrm{cmol}_{\mathrm{c}} / \mathrm{dm}^{3} ; \mathrm{Al}^{3^{+}}$ ( $\mathrm{KCl} 1 \mathrm{~mol} / \mathrm{L}$ ): $0.00 \mathrm{cmol}_{\mathrm{c}} / \mathrm{dm}^{3} ; \mathrm{H}+\mathrm{Al}$ (calcium acetate $0.5 \mathrm{~mol} / \mathrm{L}): 4.14 \mathrm{cmol}_{\mathrm{C}} / \mathrm{dm}^{3}$; SB: $6.15 \mathrm{cmol}_{\mathrm{C}} / \mathrm{dm}^{3}$; CEC $10.29 \mathrm{cmol}_{\mathrm{c}} / \mathrm{dm}^{3} ; \mathrm{V}: 59.77 \%$, organic matter (Method Boyocus): $30.07 \mathrm{~g} / \mathrm{dm}^{3}$ and clay - $65 \%$.

In January 2009, $100 \mathrm{~kg} \mathrm{P}_{2} \mathrm{O}_{5}$ were applied on the soil as simple superphosphate and $250 \mathrm{~kg} / \mathrm{ha}$, according to the 8-20-20 ( $\left.: \mathrm{P}_{2} \mathrm{O}_{5}: \mathrm{K}_{2} \mathrm{O}\right)$ formula as fertilizer during the winter forage sowing.

Table 1 - Weather data before harvesting and during drying of Tifton 85 plants (Marechal Cândido Rondon, 2009)

\begin{tabular}{|c|c|c|c|}
\hline \multirow[t]{2}{*}{ Date } & \multicolumn{3}{|c|}{ Temperature $\left({ }^{\circ} \mathrm{C}\right)$} \\
\hline & Average & Maximum & Minimum \\
\hline $07 / 29 / 2009$ & 14.2 & 18.4 & 10.6 \\
\hline $07 / 30 / 2009$ & 14.6 & 22.1 & 7.8 \\
\hline \multirow[t]{2}{*}{$07 / 31 / 2009$} & 18.2 & 23.9 & 12.8 \\
\hline & \multicolumn{3}{|c|}{ Relative humidity (\%) } \\
\hline $07 / 29 / 2009$ & 86.3 & 98 & 67 \\
\hline $07 / 30 / 2009$ & 69.5 & 94 & 34 \\
\hline \multirow[t]{2}{*}{ 07/31/2009 } & 82.7 & 91 & 68 \\
\hline & \multicolumn{3}{|c|}{ Dew point temperature $\left({ }^{\circ} \mathrm{C}\right)$} \\
\hline $07 / 29 / 2009$ & 11.8 & 13.7 & 8.3 \\
\hline $07 / 30 / 2009$ & 8.5 & 13.2 & 5.0 \\
\hline \multirow[t]{2}{*}{$07 / 31 / 2009$} & 15.2 & 18.2 & 10.8 \\
\hline & Radiation $\left(\mathrm{KJ} / \mathrm{m}^{2}\right)$ & \multicolumn{2}{|c|}{ Precipitation (mm) } \\
\hline $07 / 29 / 2009$ & 14741.711 & \multicolumn{2}{|c|}{0} \\
\hline $07 / 30 / 2009$ & 13196.150 & \multicolumn{2}{|c|}{0} \\
\hline $07 / 31 / 2009$ & 9470.634 & \multicolumn{2}{|c|}{0} \\
\hline
\end{tabular}

Source: Meteorological station of Experimental Farm at Unioeste - Marechal Cândido Rondon - PR, July, 2009.
The experiment was installed and carried out in a field for hay production that had been settled with Cynodon sp. cv. Tifton 85 , seven years before in a 1.2 ha total area. The studied intercrops were Tifton 85 without overseeding, Tifton 85 overseeded with white oat (Avena sativa L. Cv. IPR 126) and Tifton 85 overseeded with ryegrass (Lolium muliflorum Lam.). The plots dimensions were $5 \times 12 \mathrm{~m}\left(60 \mathrm{~m}^{2}\right)$.

Tifton 85 was cut at $0.05 \mathrm{~m}$ height from soil level then, after five days, the sowing of winter forages was performed, on June 4th, 2009. Grasses were sown in 0.17-m spaced rows, with a precision seed drill pulled by a tractor, using $70 \mathrm{~kg} / \mathrm{ha}$ of seeds for each overseeded species.

During the growth period of 55 days, no incidence of pests or disease was observed in the studied species and no sidedressing fertilization was carried out. The cutting management of the experimental area was performed on 07/29/2009 at 10:00 am, using mower blades by tractor. A conditioning unit with scouts of free fingers was used to standardize and increase dehydration, whose conditioning unit was applied four hours after cutting.

Dry matter yield and leaf:stem ratio were studied according to a completely randomized blocks design (CRBD) with five treatments and four replications, in which the treatments consisted of five conditions for forage growth (single Tifton 85; Tifton 85 intercropped with white oat; Tifton 85 intercropped with ryegrass, white oat intercropped with Tifton 85, ryegrass intercropped with Tifton 85).

The drying curves were studied under CRBD with ten dehydration times $(0,4,8,24,28,32,48,52,56$ and 71 hours after harvest, in a $5 \times 10$ split-plot arrangement (growth conditions to forage as main plot and dehydration time as sub-plots). For chemical composition, in vitro dry matter digestibility (IVDMD) and in vitro crude protein digestibility (IVCPD), the experimental design was used in CRDB, in a $3 \times 3$ split-plot arrangement, with three intercrops (single Tifton 85; Tifton 85- Oat and Tifton 85 - Ryegrass) as main plots and the sampling times (before harvesting, at baling and 100 days of storage) as sub-plots, with five replications.

Before mow passage, $1.0 \mathrm{~m}^{2}$ samples were collected to estimate dry matter yield in each plot. The samples were divided in two subsamples: the first one aimed at evaluating chemical composition and the second selected based on botanical composition. A portion of $100 \mathrm{~g}$ from the second subsample was taken from each species in order to separate them into leaves (leaf lamina + sheaths) and stem to determine the leaf:stem ratio after drying.

All samples were separated and packed into paper bags, weighed, placed in an oven with forced ventilation 
and maintained at $55^{\circ} \mathrm{C}$ temperature for 72 hours for drying. To determine the drying curves, $300 \mathrm{~g}$ samples were collected from each plot according to the established times. The grasses were selected and subjected to drying separately following the same methodology applied to other samples. After 71 hours of dehydration, at the moment of baling, a new sampling was performed to determine chemical composition of the material at baling time. After sampling, the material was mechanically baled in rectangular bales with an average weight of $12 \mathrm{~kg}$. They were stored under identical conditions of temperature, light and humidity in a shed, protected from rain and sunshine. The storage time was of 100 days; after that, bales were opened and a new sampling was performed to determine their chemical composition.

After drying, the samples, selected for chemical composition evaluation, were ground in a Willey mill, with 30 mesh sieve and stored in plastic bags, correctly identified, to evaluate the levels of crude protein (CP) according to the AOAC (1990), neutral detergent fiber (NDF), acid detergent fiber (ADF) according to Van Soest et al. (1991), neutral detergent insoluble protein (NDIP - expressed as $\mathrm{g} / \mathrm{kg} \mathrm{CP}$ ), acid detergent insoluble protein (ADIP - expressed as $\mathrm{g} / \mathrm{kg}$ CP), lignin, hemicellulose and cellulose (Silva \& Queiroz, 2006). In vitro DM digestibility (IVDMD) was also determined by the technique described by Tilley \& Terry (1963) adapted to the Artificial Rumen as described by Holden (1999), and in vitro crude protein digestibility (IVCPD) was determined in the residue of IVDMD by the Kjeldahl method (AOAC, 1990). The data were analyzed by statistical analysis based on the SAEG program (Sistema para Análises Estatísticas e Genéticas, version 7.0.).

The data were submitted to ANOVA using the software SAEG. The averages of dry matter yield, leaf:stem ratio, chemical composition, IVDMD and CP were compared using Tukey test at 5\% probability, while DM data of the whole plant were analyzed using linear regression models.

\section{Results and Discussion}

The dry matter yield of single Tifton 85 was higher $(\mathrm{P}<0.05)$ than the other treatments (Table 2) when compared with Tifton 85 overseeded with white oat or ryegrass, showing that there was a competition between the species and Tifton 85. The grasses of Cynodon genus have stoloniferous growth, which makes them more aggressive, while white oat and ryegrass have an upright growth. However, the chemical quality of Tifton 85 hay intercropped with white oat and Tifton 85 intercropped with ryegrass were higher (Table 3).
Table 2 - Dry matter (DM) yield and leaf:stem ratio of single Tifton 85 or Tifton 85 intercropped with winter species of forages and winter species of single forages

\begin{tabular}{lcc}
\hline & DM yield $(\mathrm{kg} / \mathrm{ha})$ & Leaf:stem ratio \\
\hline Single Tifton 85 & $4079.60 \mathrm{a}$ & $1.30 \mathrm{~b}$ \\
Tifton 85 - Oat & $1105.28 \mathrm{~b}$ & $1.44 \mathrm{~b}$ \\
Tifton 85 - Ryegrass & $1629.96 \mathrm{~b}$ & $1.50 \mathrm{~b}$ \\
Oat & $1467.68 \mathrm{~b}$ & $4.45 \mathrm{a}$ \\
Ryegrass & $1026.08 \mathrm{~b}$ & $4.81 \mathrm{a}$ \\
CV (\%) & 12.04 & 18.99 \\
\hline
\end{tabular}

Values in the column followed by the same letter do not differ $(\mathrm{P}>0.05)$ by Tukey test.

The values obtained for leaf:stem ratio of winter species (Table 2$)$ are higher $(\mathrm{P}<0.05)$ than Tifton 85 responses due to a higher leaf ratio of these species, intrinsic characteristic of the studied winter species, since tropical species tend to present greater development of stem.

Moisture content decreased after cutting, with a slight increase in the first hours of the morning, whose results were adjusted to the quadratic regression model (Figure 1). In this trial, according to a collection at 9:00 a.m., increase of humidity in the early morning, due to the accumulated dew at night was frequently observed. According to Rotz (1995), hay is hygroscopic, i.e., it can absorb or lose water to the environment. This allows that relative humidity $(\mathrm{RH})$ affect the moisture content of the material exposed to the environment. Thus, moisture acquired at night is quickly lost in a couple of hours under the sun (Jobim et al., 2007). The total drying period of hay in this experiment was of 71 hours, with average temperature conditions of $15.7^{\circ} \mathrm{C}$ and relative humidity of $79.5 \%$, which is common in this time of the year due to the weather of the region.

The nutritive value of forage is traditionally estimated by the concentration of crude protein and cell wall (NDF, ADF and lignin) by in vitro or in vivo digestibility (Paterson et al., 1994). The CP values (Table 3) of Tifton 85 intercropped with oat and Tifton 85 intercropped with ryegrass were almost $200 \mathrm{~g} / \mathrm{kg}$, with an average of $198.6 \mathrm{~g} / \mathrm{kg}$. So, there was a significant difference $(\mathrm{P}<0.05)$ of single Tifton 85 , whose average response was $132.8 \mathrm{~g} / \mathrm{kg}$. These values were the same until baling time, but, after 100 days of storage, the values of Tifton $85+$ oat and Tifton 85 + ryegrass decreased from $211.7 \mathrm{~g} / \mathrm{kg}$ to $161.3 \mathrm{~g} / \mathrm{kg}$ and from $191.2 \mathrm{~g} / \mathrm{kg}$ to $173.1 \mathrm{~g} / \mathrm{kg}$, respectively, while Tifton 85 kept at $150.8 \mathrm{~g} / \mathrm{kg} \mathrm{CP}$.

Reductions in crude protein concentrations were expected, since there were nutritional losses during storage of this component. However, crude protein is lost at a slower rate than carbohydrates in forage (Buckmaster et al., 1989). According to Enoh et al. (2005), small reductions in 

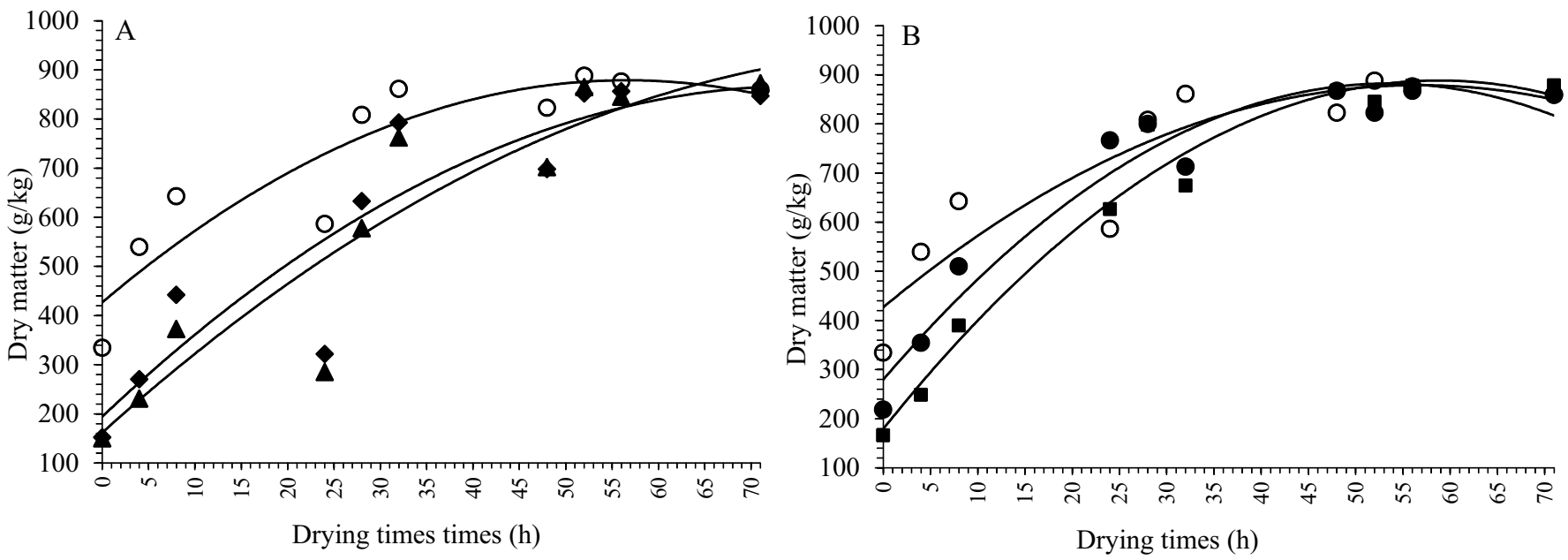

Figure 1 - Effect of drying period on the concentration of total dry matter (DM) in hay oat (A) $\left(\boldsymbol{\Delta}, \mathrm{Y}=16.1942+1.6971 * * \mathrm{x}-0.0092 * * \mathrm{x}^{2}\right.$; $\mathrm{R}^{2}$ : 0.87), ryegrass $(\mathrm{A})\left(\bullet, \hat{\mathrm{Y}}=19.4326+1.7874 * * \mathrm{x}-0.0118 * * \mathrm{x}^{2} ; \mathrm{R}^{2}: 0.84\right)$, Tifton $85+$ oat $(\mathrm{B})(\mathbf{\square}, \hat{\mathrm{Y}}=17.9110+2.4128 * * \mathrm{x}-$ $0.0205 * * x^{2} ; R^{2}$ : 0.97); Tifton $85+$ ryegrass (B) $\left(\hat{Y}=27.9531+2.2562 * * x-0.0211 * * x^{2} ; R^{2}: 0.95\right)$ and single Tifton 85 (A, B) $\left(\mathrm{O}, \hat{\mathrm{Y}}=42.6882+1.5969 * * \mathrm{x}-0.0141^{* *} \mathrm{x}^{2} ; \mathrm{R}^{2}: 0.84\right)$.

Table 3 - Chemical composition and in vitro digestibility of dry matter (IVDM) and crude protein (IVDCP) of Tifton 85 and intercrops with white oat and ryegrass using a conditioning unit, before cutting, at baling and after 100 days of storage ${ }^{1}$

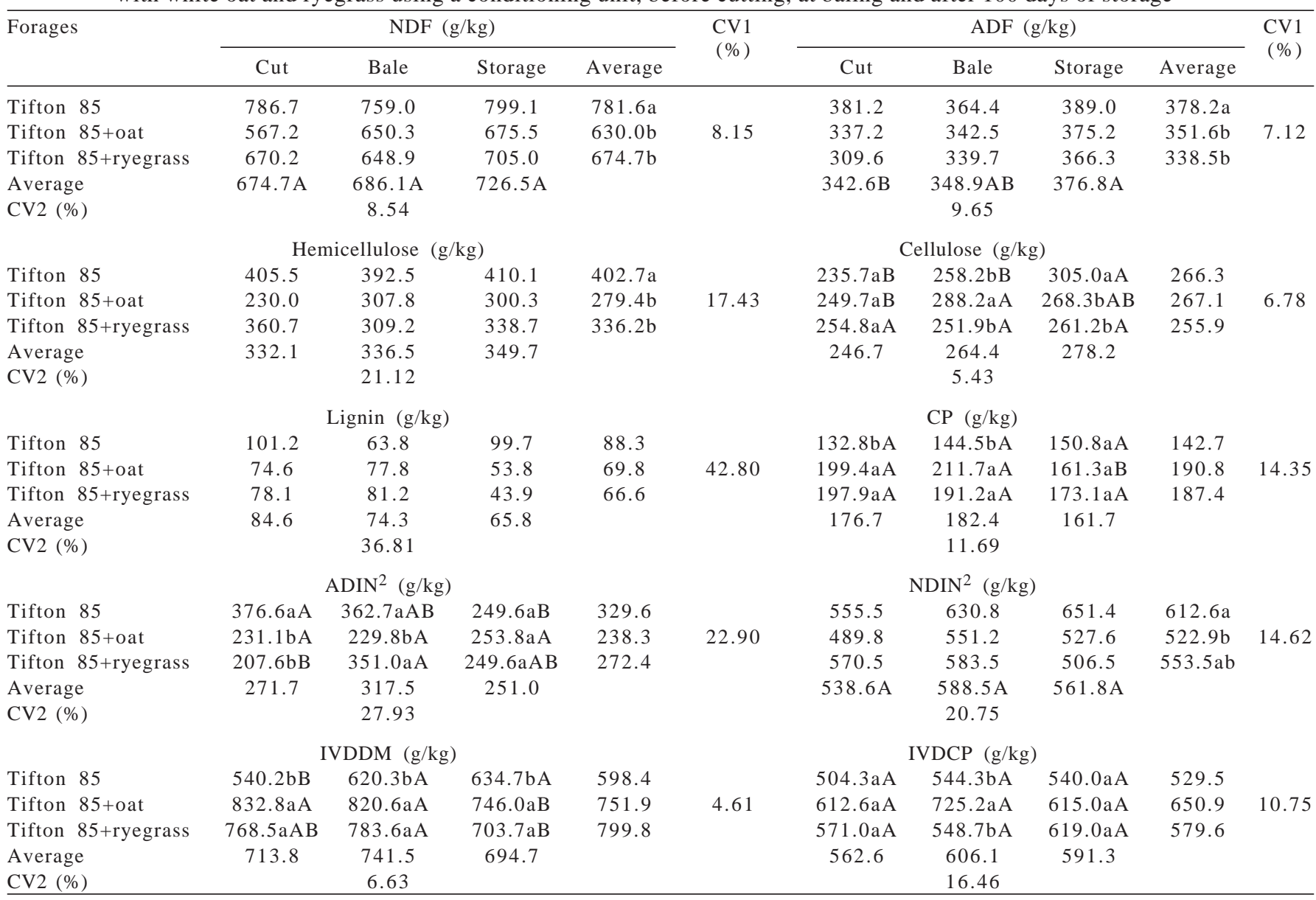

NDF - neutral detergent fiber; ADF - acid detergent fiber; CV1 (\%): coeficiente de variação da parcela; CV2 (\%): coeficiente de variação da subparcela; ADIN - acid detergent insoluble nitrogen; NDIN - neutral detergent insoluble nitrogen; CP - crude protein.

${ }^{1}$ Values followed by the same upper-case letter in the row and lower-case letter in the column do not differ by Tukey test (5\%).

${ }^{2}$ Values expressed $\mathrm{g} / \mathrm{kg}$ crude protein. 
protein contents of stored hay may be related to a continuous and slow dissipation of non-protein nitrogen formed by breathing associated with the drying process.

Fiber content has been used as a negative index of diet quality, because it represents the least digestible fraction of feed. However, fiber is required for normal functioning and metabolism of the rumen, so its quality becomes an important factor on diets of ruminants, particularly in dairy cows (Matos, 1989).

White oat and ryegrass increased hay $\mathrm{CP}$, but, there was no significant difference between crops $(\mathrm{P}>0.05)$ for crude protein yield, which was: 455.13; 515.71 and $520.94 \mathrm{~kg} / \mathrm{ha}$ CP for treatments as Tifton 85 + oat; Tifton 85 + Ryegrass and single Tifton 85, respectively.

The NDF values werehigher for single Tifton $85(781.6 \mathrm{~g} / \mathrm{kg})$ in all stages (from cutting to storage) and differed significantly from intercrops $(\mathrm{P}<0.01)$. These values are due to the lower leaf:stem ratio presented by Tifton 85 (Table 2) and are above the recommended level, which would be $550-600 \mathrm{~g} / \mathrm{kg}$ on a dry matter basis (Mertens, 1994). Moreira et al. (2006) obtained NDF values of $717 \mathrm{~g} / \mathrm{kg}$ for single Tifton 85 , while Castagnara et al. (2011) studied the use of a conditioning unit that was similar to this trial and registered contents of $80 \%$ NDF for Tifton 85 hay.

The values of ADF at the cutting moment for Tifton 85 were $381.2 \mathrm{~g} / \mathrm{kg}$, differing significantly from the intercrops. However, at baling time and after storage, there was no significant difference between intercrops and single Tifton 85 , whose average datum was $376.9 \mathrm{~g} / \mathrm{kg}$ in storage. At cutting time, when Tifton 85 was intercropped with ryegrass, the ADF value was $309.6 \mathrm{~g} / \mathrm{kg}$. However, it increased to $366.3 \mathrm{~g} / \mathrm{kg}$ after storage, so it was equivalent to the other forages.

Cellulose is the most important constituent of the cell wall and its percentage can vary from 20 to $40 \%$ (Van Soest, 1994). The cellulose concentration varied only at baling time between intercrops, and was superior when white oat was intercropped with Tifton 85. After storage, the average value between treatments was $27.81 \%$. Single Tifton 85 showed a progressive increase in cellulose values according the stages. At harvest time, the response was $235.7 \mathrm{~g} / \mathrm{kg}$; at baling time, the record was $258.5 \mathrm{~g} / \mathrm{kg}$ and after storage, $305.0 \mathrm{~g} / \mathrm{kg}$. Enoh et al. (2005) observed increases in cellulose levels of Brachiaria ruziziensis stored hay. During a study with Tifton 85 hay subjected to two conditions, Castagna et al. (2011) observed no changes in hemicellulose concentrations after storage.

Hemicellulose is a heterogeneous collection of amorphous polysaccharides with a very low degree of polymerization when compared with cellulose (Van Soest, 1994). There was no season effect on hemicellulose contents, but differences were observed between treatments and at baling time; Tifton 85 showed $41.01 \mathrm{~g} / \mathrm{kg}$, while the intercrops presented averages of $31.95 \mathrm{~g} / \mathrm{kg}$. Enoh et al. (2005) have worked with Brachiaria ruziziensis hay that was stored for up to 140 days, while Castagnara et al. (2011) have worked with Tifton 85 hay stored for 100 days, but none of them observed changes in cellulose contents.

Lignin is a constituent of the cell wall and negatively influences the stem tissue degradability (Jung \& Engels, 2002). Its excess can make dietary protein unavailable, causing a reduction in consumption (Rogerio et al., 2007). Storage showed the only significant difference for this variable, with superior values $(99.6 \mathrm{~g} / \mathrm{kg}$ ) for Tifton 85 in relation to the average value of the other treatments $(48.8 \mathrm{~g} / \mathrm{kg})$. These responses are in accordance with the results obtained by Enoh et al. (2005).

The results for fibrous components of forage are similar to those observed by Neres et al. (2011) when they studied Tifton 85 hay overseeded with white oat or ryegrass without managing with a conditioning unit to dehydration. According to Buckmaster et al. (1989), changes in fibrous components, which were observed in this study, are due to dry matter losses that naturally occur with hay storage. There is a reduction in nonstructural carbohydrates with dry matter loss, while fibrous components of forage remain, but their concentrations are increased due to dry matter losses.

Regarding the NDIP contents in relation to CP, there were no significant differences between the intercrops at any moment of hay production. These results stress that there were no conditions of high temperatures on the processes of hay production and storage, because NDIP may be naturally present in plants or can be considered an estimate of damage caused by heat (Silva \& Queiroz, 2006).

The study concerning NDF components is primordial for nutritional evaluation of tropical forages, because NDF components cannot be considered as homogeneous nutrition feedstuff (Van Soest, 1994), thus, CP can lead to distortions in estimates of fraction, apparently digestible from chemical composition of feeds produced under tropical conditions (Detmann et al., 2008).

The quantification of ADIP fraction is crucial to a study concerning conserved quality forages, because this protein fraction is unavailable to ruminants (Buckmaster et al., 1989). In this trial, the single Tifton 85 showed higher values of ADIP during harvest, which remained at baling time, but they were equal to the intercrops after storage.

For the intercrops, when ryegrass was used, the ADIP content increased with the dehydration process, but 
decreased with storage; however, but when it was intercropped with white oat, no changes were observed (Table 3).

The changes observed for ADIP levels may be related to breathing during dehydration, because, according to Buckmaster et al. (1989), there is some heat generation caused by a certain reduced availability of protein in hay. Based on the results, it can be inferred that the DM content of forages at baling time was appropriate and did not cause increase in temperature during storage, because according to Van Soest (1994), increase in ADIP levels occur when moisture is high and temperature reaches values above $55^{\circ} \mathrm{C}$. The estimate of this fraction becomes relevant due to its potential use as a predictor or estimator of protein, since ADIP is not available to rumen microorganisms or intestinal digestibility (Clipes et al., 2006). Aguiar et al. (2006) studied tropical grass hays and found NDIP values ranging from 45.45 to $54.66 \%$, while Gobbi et al. (2005) studied Brachiaria decumbens Stapf. hay and found $488 \mathrm{~g} / \mathrm{kg}$ of total $\mathrm{N}$ bound to the cell wall and $248 \mathrm{~g} / \mathrm{kg}$ of $\mathrm{N}$ bound to the ADF.

The quantification of CP associated with NDF and ADF (NDIP and ADIP) is important in the study of hay protein degradability, as well as their ratio in relation to total CP and possible relations of these components with digestibility and the nutrients consumption of these forages (Aguiar et al., 2006).

Digestibility is one of the characteristics associated with nutritional value of the most important forage plants (Poppi et al., 1987), so there is an important influence on forage consumption. Studies involving several forage species have consistently showed increases in consumption as well as in digestibility, whose values range from 400 and $800 \mathrm{~g} / \mathrm{kg}$ (Lyons et al., 1999). In this study, the values are within this range; however, the intercrops provided more digestible forage than Tifton 85 . The digestibility values increased regarding the effects of dehydration process and storage, for Tifton 85, but, for intercrops, dehydration did not affect digestibility, although this one was reduced by the storage. This process is due to the losses of nonstructural carbohydrates that occur during storage, which reduce digestibility of hay and its potential of consumption by animals (Buckmaster et al., 1989). According to Carter (2007), reductions in IVDMD cause not only an economic loss on the hay value, but also additional expenses if there is any need to meet the requirements that could be supplied only with hay.

The CP digestibility was not influenced by the processes of hay conservation, but at baling time, it was higher in the intercrop with Tifton 85 + oats. This absence of changes in protein digestibility with storage reveals that non-enzymatic reactions were not recorded in soluble carbohydrates, amine and amino acids groups during the preservation processes, which, according to Van Soest (1994), occur at high moisture and temperature. According to Ball et al. (1998), digestible crude protein ratio can decrease, especially if hay heats up due to excessive moisture. Morais et al. (2004) registered digestibility of $700 \mathrm{~g} / \mathrm{kg}$ CP in dwarf elephant-grass, while Lana et al. (2007) studied the in vitro CP degradability of foods and found degradability values of 522 and $806 \mathrm{~g} / \mathrm{kg}$ for Tifton 85 hay, with and without ammonization, respectively.

\section{Conclusions}

The overseeding of white oat or ryegrass in grazing of Tifton 85 reduces the dry matter production per unit area, but increases leaves ratio in a forage produced by the increase of the leaf:stem ratio. Single Tifton 85 has faster dehydration rate in the first hours after cutting; however, conditioned to the weather conditions at the end of 71 hours of dehydration, hay produced by single Tifton 85 or intercropped with white oat or ryegrass reaches the right dry matter content for baling and storage time. The overseeding of white oat or ryegrass in fields of Tifton 85 for hay production during the winter improves the nutritive value of the hay produced. Nevertheless, storage for 100 days causes reduction in the in vitro dry matter digestibility and crude protein concentrations.

\section{Reference}

AGUIAR, E.M.; COSTA LIMA, G.F.; SANTOS, M.V.F. et al. Rendimento e composição químico-bromatológica de fenos triturados de gramíneas tropicais. Revista Brasileira de Zootecnia, v.35, n.6, p.2226-2233, 2006.

ASSOCIATION OF OFFICIAL ANALYTICAL CHEMISTS - AOAC. Official methods of analysis. 15.ed. Virginia: Arlington, 1990. 1117p,

BALL, D.; BADE, D.; LACEFIELD, G. et al. Minimizing losses in hay storage and feeding. Clemson: National Forage Information, 1998. p.1-16. (Circular 98-1).

BUCKMASTER, D.R.; ROTZ, C.A.; MERTENS, D.R. A model of alfalfa hay storage. Transactions of the ASAE, v.32, n.1, p.30-36, 1989

CARTER, J. Maintain or improve stored hay quality. Electronic data information source of UF/IFAS extension (EDIS) document AN173. 2007. Available at: <http://edis.ifas.ufl.edu/pdffiles/AN/ AN18500.pdf $>$. Accessed on: Aug. 25, 2011.

CASTAGNARA, D.D.; AMES, J.P.; NERES, M.A. Use of conditioners in the production of Tifton 85 grass hay. Revista Brasileira de Zootecnia, v.40, n.10, p.2083-2090, 2011

CLIPES, R.C.; DETMANN, E.; SILVA, J.F.C. et al. Evaluation of acid detergent insoluble protein as an estimator of rumen nondegradable protein in tropical grass forages. Arquivos Brasileiros de Medicina Veterinária e Zootecnia, v.58, n.4, p.694-697, 2006. 
DETMANN, E.; MAGALHÃES, K.A.; VALADARES FILHO, S.C. et al. Desenvolvimento de um submodelo bicompartimental para estimação da fração digestível da proteína bruta em bovinos a partir da composição química dos alimentos. Revista Brasileira de Zootecnia, v.37, n.12, p.2215-2221, 2008.

DOMINGUES, J.L. Uso de volumosos conservados na alimentação de eqüinos. Revista Brasileira de Zootecnia, v.28, p.259-269, 2009 (supl. especial).

ENOH, M.B.; KIJORA, C.; PETERS, K.J. et al. Investigation on change of forage quality at harvesting, during hay making and storage of hay harvested at different growth stages in the Adamawa plateau of Cameroon. Livestock Research for Rural Development, v.17, n.5, p.1-6, 2005

GOBBI, K.F.; GARCIA, R.; GARCEZ NETO, A.F. et al. Composição química e digestibilidade in vitro do feno de Brachiaria decumbens Stapf. tratado com uréia. Revista Brasileira de Zootecnia, v.34, n.3, p.720-725, 2005.

HOLDEN, L.A. Comparison of methods of in vitro matter digestibility for ten feeds. Journal of Dairy Science, v.2, n.8, p.1791-1794, 1999

INSTITUTO AGRONÔMICO DO PARANÁ - IAPAR. [2006]. Cartas climáticas do Paraná. Available at: <http://200.201.27.14/ Site/Sma/Cartas_Climaticas/Classificação__Climaticas.htm>. Accessed on: Sep. 3, 2008.

JOBIM, C.C.; NUSSIO, L.G.; REIS, R.A. et al. Avanços metodológicos na avaliação da qualidade da forragem conservada. Revista Brasileira de Zootecnia, v.36, p.101-119, 2007 (supl. especial).

JUNG, H.G.; ENGELS, F.M. Alfalfa stem tissues: cell, wall deposition, composition and degradability. Crop Science, v.24, n.2, p.524-534, 2002.

LANA, R.P.; LEOPOLDINO, W.M.; OLIVEIRA, J.S. et al. Parâmetros da degradação protéica ruminal de diferentes alimentos e rações estimados por técnica in vitro. Arquivos Brasileiros de Medicina Veterinária e Zootecnia, v.59, n.2, p.414-422, 2007.

LYONS, R.K.; MACHEN, R.; FORBES, T.D.A. Understanding forage intake in range animals. Texas Agricultural Extension Service, Uvalde, 1999. p.6. Available at: <http://wildlife.tamu. edu/publications/L5152>. Accessed on: Mar. 5, 2009.

MATOS, L.L. Utilização de fibra pelos ruminantes. In: MINI SIMPÓSIO DO COLÉGIO BRASILEIRO DE NUTRIÇÃO ANIMAL, 2., 1989, Campinas. Anais... Campinas: CBNA, 1989. p.91.

MERTENS, D.R. Regulation of forage intake. In: FAHEY JR., G.R. (Ed.) Digestibility in vitro, haymaking. Madison: American Society of Agronomy, 1994. p.450-493.

MORAIS, J.A.S.; KOZLOSKI, G.V.; REFFATTI, M.V. et al. Nível de consumo e sua relação com o valor nutritivo do feno de capim-elefante anão (Pennisetum purpureum Schum. cv. Mott) oferecido a ovinos. In: REUNIÃO ANUAL DA SOCIEDADE BRASILEIRA DE ZOOTECNIA, 41., 2004, Campo Grande. Anais... Campo Grande: Sociedade Brasileira de Zootecnia, 2003. (CD-ROM)

MOREIRA, A.L.; REIS, R.A.; SIMILI, F.F. et al. Época de sobressemeadura de gramíneas anuais de inverno e de verão no capim Tifton 85: valor nutritivo. Ciência e Agrotecnologia, v.30, n.2, p. 335-343, 2006.

NERES, M.A.; CASTAGNARA, D.D.; MESQUITA, E.E. Production of tifton 85 hay overseeded with white oat or ryegrass. Revista Brasileira de Zootecnia, v.40, n.8, p.1638-1644, 2011.

PATERSON, J.A.; BELEYA, R.L.; BOWMAN, J.P. et al. The impact of forage quality and supplementation regimen on ruminant animal intake and performance. In: FAHEY JR., G.C. (Ed.). Forage quality, evaluation and utilization. Madison: American Society of Agronomy; Crop Science Society of America, 1994. p.59-114.

POPPI, D.P.; HUGHES, T.P.; LHUILLIER, P.J. Intake of pasture by grazing ruminants. In: NICOL, A.M. (Ed). Livestock feeding on pasture. Hamilton: New Zealand Society of Animal Production, 1987. p.55-64.

REIS, R.A.; SOLLENBERGER, L.E.; URBANO, D. Impact of overseeding cool-season annual forages on spring regrowth of Tifton 85 bermudagrass. In: INTERNATIONAL GRASSLAND CONGRESS, 19., 2001, São Pedro. Proceedings... São Pedro: Brazilian Society of Animal Husbandry, 2001. p.295-297.

ROGERIO, M.C.P.; BORGES, I.; NEIVA, J.N.M. et al. Valor nutritivo do resíduo da indústria processadora de abacaxi (Ananas comosus L.) em dietas para ovinos. 1. Consumo, digestibilidade aparente e balanços energético e nitrogenado. Arquivos Brasileiros de Medicina Veterinária e Zootecnia, v.59, n.3, p.773-781, 2007.

ROTZ, C.A. Field curing of forage. In: MOORE, K.J.; KRAL, D.M.; VINEY, M.K. (Eds). Post-harvest physiology and preservation of forages. Madison: American Society of Agronomy, 1995. p.39-66.

SILVA, D.J.; QUEIROZ, A.C. Análise de alimentos: métodos químicos e biológicos. Viçosa, MG: UFV, 2006. 235p.

TILLEY, J.M.A.; TERRY, R.A. A two stage technique for the in vitro digestion of forage crops. Journal of the British Grassi and Society, v.18, n.2, p.104-111, 1963.

VAN SOEST, P.J. Nutritional ecology of the ruminant. Ithaca: Constock Publishing Associates, 1994. 476p.

VAN SOEST, P.J.; ROBERTSON, J.B.; LEWIS, B.A. Methods for dietary fiber, neutral detergent fiber, and non-starch polysaccharides in relation to animal nutrition. Journal of Dairy Science, v.74, n.10, p.3583-3597, 1991. 